Avaiable online at www.banglajol.info

Bangladesh J. Sci. Ind. Res. 43(3), 359-368, 2008
BANGLADESH JOURNAL OF SCIENTIFIC AND INDUSTRIAL RESEARCH

E-mail: bjsir07gmail.com

\title{
Growth and Yield of Soybean (Glycine $\max$ L.) as Influenced by Phosphorus
}

\author{
R. M. Morshed,*ª M. M. Rahman and M. A. Rahman ${ }^{\mathrm{b}}$ \\ ${ }^{a}$ Department of Botany, Jahangirnagar University, Savar, Dhaka -1342, \\ Bangladesh and ${ }^{b}$ Soil Resource Development Institute, Regional Laboratory, \\ Mymensingh, Bangladesh.
}

\begin{abstract}
The experiment was conducted to find out the influence of phosphorus $(\mathrm{P})$ on growth and yield of soybean (Glycine max L., variety: G-2). The treatments were: control $\left(\mathrm{P}_{1}\right)$ and with the application of 50\% $\left(\mathrm{P}_{2}\right), 75 \%\left(\mathrm{P}_{3}\right), 100 \%\left(\mathrm{P}_{4}\right), 125 \%\left(\mathrm{P}_{5}\right)$ and $150 \%\left(\mathrm{P}_{6}\right)$ of the BARC recommended dose of $\mathrm{P}$. Nitrogen, K and $\mathrm{S}$ were applied as blanket as per BARC recommendation. Seeds were inoculated with Bradyrhizobium inoculum before sowing. All the treatments of $\mathrm{P}$ application showed higher growth than that of the control. $\mathrm{P}_{5}$ treatment (11.25 $\mathrm{kg} \mathrm{P} \mathrm{ha}^{-1}$ ) showed maximum growth and yield, which was 84.73\% higher than that of control. The yield changed as a parabola curve with the increase of P application. The yield component, namely number of pods plant ${ }^{-1}$, number of seeds $\operatorname{pod}^{-1}$, pod weight plant $^{-1}$ and number of seed plant ${ }^{-1}$ increased with the increase of P levels up to $11.25 \mathrm{~kg} \mathrm{P} \mathrm{ha}^{-1}$. The application of $\mathrm{P}$ at $11.25 \mathrm{~kg} \mathrm{ha}^{-1}$ (25\% higher over BARC recommendation) produced the highest seed yield of soybean $\left(7.50 \mathrm{~g} \mathrm{plant}^{-1}\right)$. So, for better yield of soybean in silty clay loam soil of Jahangirnagar University farm, application of P should be increased 25 \% higher over BARC recommendation.
\end{abstract}

Key words: Soybean, Phosphorus, Growth, Yield

\section{Introduction}

Soybean (Glycine max L. Merrill) is an important and well-recognized oil and protein containing crop of the world. The approximate composition of soybean is 40 $45 \%$ protein, $18-20 \%$ edible oil, $24-26 \%$

carbohydrate and a good amount of vitamins
(Kaul and Das, 1986). The soybean oil is cholesterol free and easily acceptable diet. The protein content in soybean is nearly double than other pulses. On an average Bangladeshi diet only of 8-10 percent of the protein intake originate from animal sources,

*Corresponding authour, E-mail: rathimorshed@yahoo.com 
the rest can be met from plant sources by increasing the consumption of soybean and pulses. The children who are intolerant to cow's milk, a substitute like soyamilk can be provided for them. The people who are allergic to cow's milk develop hypolactasia resulting in lactose intolerance, can safely consump soyamilk. It is grown in Bangladesh with no nitrogen fertilizer like urea. As a result, the average yield does not appear to be satisfactory. However, there is a scope for improvement of this yield through judicious application of chemical fertilizers and biofertilizers. Phosphorus has beneficial effects on both nodulation and nitrogen fixation capacity of soybean (Gates, 1975). The most obvious effect of phosphorus is on the plant root system. It promotes early root formation and thus formation of lateral fibrous and healthy roots, which is very important for nodule formation and fixing atmospheric nitrogen. Phosphorus application significantly increases dry matter production as well as yield and yield contributing charac- ters of soybean (Idri et al., 1989). Singh et al.1973 have also reported the positive role of phosphorus to increase the growth and yield of soybean. Unfortunately, there is a lack of sufficient work on the nutrient requirement, particularly phosphorus in presence of seed inoculation with effective strains of bradyrhizobia for successful soybean cultivation in Bangladesh. The present study was therefore, undertaken to study the influnce of phosphorus application on growth and yield of soybean.

\section{Materials and Methods}

A pot experiment was conducted at the experimental space of the Department of Botany, Jahangirnagar University, Savar, Dhaka, during rabi season of 2004-2005 with a view to find out the optimum level of phosphorus fertilizer for soybean cultivation. The physical and chemical properties of the experimental soil are presented in Table I. The experiment was laid out in a complete

Table I. Initial physical and chemical properties of experimental soil

\begin{tabular}{l|l}
\hline \multicolumn{1}{c|}{ Properties } & \multicolumn{1}{c}{ Value } \\
\hline Soil texture & Silty- clay- loam \\
Soil pH & 5.30 \\
Soil organic matter (\%) & 2.02 \\
Total nitrogen (\%) & 0.04 \\
Available phosphorus (ppm) & 16.36 \\
Exchangeable potassium (meq. /100 g soil) & 0.32 \\
Available sulphur (ppm) & 27.82 \\
Exchangeable calcium (meq. /100 g soil) & 5.75 \\
Exchangeable magnesium (meq. /100 g soil) & 2.25 \\
\hline
\end{tabular}


randomized design (CRD) with six levels of $\mathrm{P}$ treatments. Each treatment was replicated thrice. The treatments and their levels were: $\mathrm{P}_{1}=$ Without $\mathrm{P}$ (control), $\mathrm{P}_{2}=50 \% \mathrm{P}$ of BARC recommendation ie, P @ $4.5 \mathrm{~kg} \mathrm{ha}^{-1}$, $\mathrm{P}_{3}=75 \% \mathrm{P}$ of BARC recommendation ie, $\mathrm{P}$ @ $6.75 \mathrm{~kg} \mathrm{ha}^{-1}, \mathrm{P}_{4}=100 \% \mathrm{P}$ of BARC recommendation ie, $\mathrm{P} @ 9.00 \mathrm{~kg} \mathrm{ha} \mathrm{h}^{-1}, \mathrm{P}_{5}=$ 125\% P of BARC recommendation ie, P @ $11.25 \mathrm{~kg} \mathrm{ha}^{-1}, \mathrm{P}_{6}=150 \% \mathrm{P}$ of BARC recommendation ie, P@13.50 kg ha ${ }^{-1}$. Phosphorus was applied as T.S.P. In addition to P, other nutrients such as N, K and S were applied @ $21.16 \mathrm{~kg}, 7.50 \mathrm{~kg}$ and $1.80 \mathrm{~kg} \mathrm{ha}^{-1}$, respectively as urea, Muriate of potash (MOP) and gypsum (Fertilizer Recommendation Guide1997, BARC). Each pot (20 cm diameter) was filled with $5.66 \mathrm{~kg}$ of previously prepared grounded and dried soil. Pots were laid out according to the experimental design and placed one meter apart from each other for accumulation of sufficient sunlight. Fertilizers were applied in each pot according to treatments as basal dose. Soybean variety G-2 (Bangladesh Soybean-4) was used as the test crop in the experiment. Required amount of soybean seeds were inoculated with peat based inoculant (obtained from BARI) of Bradyrhizobium strain (BARI RGm-902) immediately before sowing. Three to four seeds per pot were sown on December 16, 2004. Necessary shading by newspaper was provided to preserve soil moisture until germination. Initially 3 plants were allowed to grow, but two weaker plants were uprooted at 10 days after germination keeping the healthiest one to grow. Weeding and other intercultural operations were done whenever necessary to keep the plants healthy. As needed, insecticide (Dersban 20 EC) was sprayed to control hairy caterpillar in all the pots. The plant was collected from each pot after 123 days from the date of sowing. Data on different plant parameters was statistically analysed by using Analysis of Variance (ANOVA) and Duncan's Multiple Range Test (DMRT) as outlined by Gomez and Gomez (1984).

\section{Results and Discussion}

\section{Plant height}

Plant height increased steadily up to 11.25 kg $\mathrm{P}$ ha $^{-1}$ and then declined (Table II). Treatment $\mathrm{P}_{5}$ produced the highest plant height $(61.67 \mathrm{~cm})$ which was $40.16 \%$ higher than that of control treatment $\left(\mathrm{P}_{1}\right)$. Treatment $\mathrm{P}_{4}$ and $\mathrm{P}_{5}$ are statistically identical. The lowest plant height $(44.00 \mathrm{~cm})$ was recorded in control treatment. This result was in agreement with that of Shivakumar and Sidramappa (2004), where it was reported that plant height of soybean was highest with 20 kg P ha-1. Ramasamy et al., (2000) also found that plant height of soybean increased with P at $80 \mathrm{~kg} \mathrm{ha}^{-1}$. Mohan and Rao (1997) also found that plant height of soybean increased with increasing $\mathrm{P}$ and Mo rates.

\section{Root length}

The effect of different levels of phosphorus on the root length of soybean was found significant (Table II). It was observed that the 
root length per plant increased up to the dose of $11.25 \mathrm{~kg} \mathrm{P}$ ha $^{-1}$ of $\mathrm{P}_{5}$ treatment and then decreased above this level. The maximum root length $(31.00 \mathrm{~cm})$ was produced by $\mathrm{P}_{5}$ treatment which was $27.41 \%$ higher than that of control treatment. The lowest root length $(24.33 \mathrm{~cm})$ was recorded by control treatment. Similar results observed by Singh and Ahuja (1985) in groundnut and Singh et. al. (2005) in lentil. Ramasamy et al., (2000) also observed that $\mathrm{P}$ at $80 \mathrm{~kg} \mathrm{ha}^{-1}$ increased root length per plant of soybean.

\section{Dry weight of shoot}

The effect of different levels of phosphorus with the association of Bradyrhizobium inoculation on the dry weight of shoot of soybean was found significant (Table II). The maximum dry weight of shoot (3.68 g) was produced by $11.25 \mathrm{~kg} \mathrm{P}$ ha ${ }^{-1}$ at $\mathrm{P}_{5}$ treatment which was $90.67 \%$ higher than that of control treatment. With the increase of different levels of phosphorus fertilizer increased the dry weight of shoot up to $11.25 \mathrm{~kg} \mathrm{P} \mathrm{ha}^{-1}$ and above this level the shoot dry weight decreased. The lowest dry weight of shoot (1.93 g) was noted by control treatment. ElHabbasha et. al. (2005) noticed that increasing $\mathrm{P}$ levels increased stem dry weights per plant of groundnut. Meshram et. al. (2000) also found that among the $\mathrm{P}$ treatments, rock phosphate (RP) recorded the highest values for shoot dry weight (6.97 g per plant) of chickpea.

\section{Dry weight of root}

Data on the dry weight of root of soybean as influenced by $\mathrm{P}$ fertilization are shown in Table II. Average dry weight of root per plant varied insignificantly from 0.97 to $1.27 \mathrm{~g}$ due to the treatment variations. Dry weight of root increased gradually with the increasing rate of $\mathrm{P}$ application up to $11.25 \mathrm{~kg} \mathrm{P}$

Table II. Effect of phosphorus on growth and nodulation of soybean

\begin{tabular}{l|c|c|c|c|c|c}
\hline \multicolumn{1}{c|}{ Treatment } & $\begin{array}{c}\text { Plant height } \\
\text { plant }^{-1} \\
(\mathrm{~cm})\end{array}$ & $\begin{array}{c}\text { Root length } \\
\text { plant }^{-1} \\
(\mathrm{~cm})\end{array}$ & $\begin{array}{c}\text { Dry weight } \\
\text { of shoot } \\
\text { plant }^{-1}(\mathrm{~g})\end{array}$ & $\begin{array}{c}\text { Dry weight } \\
\text { of root } \\
\text { plant }^{-1}(\mathrm{~g})\end{array}$ & $\begin{array}{c}\text { Number } \\
\text { of podules } \\
\text { plant }^{-1}\end{array}$ & $\begin{array}{c}\text { Dry weight } \\
\text { of nodules }^{-1} \\
\text { plant }^{-1}(\mathrm{~g})\end{array}$ \\
\hline $\mathrm{P}_{1}\left(0 \mathrm{~kg} \mathrm{ha}^{-1}\right)$ & $44.00 \mathrm{e}$ & $24.33 \mathrm{c}$ & $1.93 \mathrm{~d}$ & 0.97 & 2.33 & 0.110 \\
$\mathrm{P}_{2}\left(4.50 \mathrm{~kg} \mathrm{ha}^{-1}\right)$ & $49.33 \mathrm{~d}$ & $25.67 \mathrm{bc}$ & $2.14 \mathrm{~d}$ & 1.00 & 6.00 & 0.137 \\
$\mathrm{P}_{3}\left(6.75 \mathrm{~kg} \mathrm{ha}^{-1}\right)$ & $51.33 \mathrm{~cd}$ & $27.00 \mathrm{bc}$ & $2.53 \mathrm{~cd}$ & 1.06 & 6.67 & 0.140 \\
$\mathrm{P}_{4}\left(9.00 \mathrm{~kg} \mathrm{ha}^{-1}\right)$ & $58.00 \mathrm{ab}$ & $28.00 \mathrm{ab}$ & $3.23 \mathrm{ab}$ & 1.10 & 6.67 & 0.163 \\
$\mathrm{P}_{5}\left(11.25 \mathrm{~kg} \mathrm{ha}^{-1}\right)$ & $61.67 \mathrm{a}$ & $31.00 \mathrm{a}$ & $3.68 \mathrm{a}$ & 1.27 & 10.33 & 0.170 \\
$\mathrm{P}_{6}\left(13.50 \mathrm{~kg} \mathrm{ha}^{-1}\right)$ & $55.67 \mathrm{bc}$ & $27.33 \mathrm{bc}$ & $2.96 \mathrm{bc}$ & 1.07 & 6.33 & 0.153 \\
$\mathrm{LSD}$ & 4.944 & 3.081 & 0.634 & $\mathrm{NS}$ & $\mathrm{NS}$ & $\mathrm{NS}$ \\
$\mathrm{CV}(\%)$ & 5.21 & 6.36 & 12.97 & 16.37 & 21.25 & 15.26 \\
\hline
\end{tabular}

Means in a column followed by same letter (s) are not significantly different at 5\% level of DMRT NS = Not significant 
$\mathrm{ha}^{-1}$, but above this rate dry weight of root decreased. This result showed similarities with the findings of Singh et al. (1987) in pigeon pea, Singh and Ahuja (1985) in groundnut and Singh et. al. (2005) in lentil.

\section{Number of nodules}

Bradyrhizobium inoculum along with different levels of $\mathrm{P}$ produced higher number of nodules per plant of soybean (Table II). Number of nodules increased insignificantly with increment level of P up to $11.25 \mathrm{~kg} \mathrm{ha}^{-1}$ and beyond which it was decreased. The increment of nodules per plant due to inoculation with $\mathrm{P}$ application at the rate of $\mathbf{1 1 . 2 5}$ $\mathrm{kg} \mathrm{ha}^{-1}$ was $343.35 \%$ higher over inoculated control plant. The highest number of nodules (10.33) was found in $P_{5}$ treatment and the lowest number of nodules (2.33) was found in control plants. The results of the present study in respect of number of nodules per plant were very close to the findings of Singh and Bajpai (1990), where they reported that nodulation of soybean was significantly affected by phosphorus levels and the highest number of nodules was recorded at $100 \mathrm{~kg} \mathrm{P}_{2} \mathrm{O}_{2}$ ha $^{-1}$. Sharma and Namdeo (1999) also observed that root nodulation of soybean was greatest with $75 \mathrm{~kg} \mathrm{P} \mathrm{ha}^{-1}$ and Rhizobium + FYM +PSB.

\section{Dry weight of nodules}

Dry weight of nodules was also insignificantly increased with increasing rate of $\mathrm{P}$ application up to $11.25 \mathrm{~kg} \mathrm{ha}^{-1}$ at $\mathrm{P}_{5}$ treat- ment (Table II). Further addition of P (above $11.25 \mathrm{~kg} \mathrm{P} \mathrm{ha}^{-1}$ ) progressively decreased the dry weight of nodules of soybean. Maximum dry weight ( 0.170 gm plant $^{-1}$ ) of nodule was recorded at $\mathrm{P}_{5}$ treatment which was $54.55 \%$ higher as compared to control plants. The results of the present study in respect of nodule weight per plant were very close to the findings of Singh and Bajpai (1990), where they reported that the highest weight of nodules of soybean were obtained at $100 \mathrm{~kg}$ $\mathrm{P}_{2} \mathrm{O}_{5}$ ha $^{-1}$. Hoque et al. (1980) observed a positive linear effect of variable phosphorus rate on the nodule weight per plant of soybean at $50 \%$ flowering.

\section{Number of pods per plant}

Different levels of phosphorus with Bradyrhizobium inoculation significantly influenced the number of pods per plant of soybean (Table III). The number of pods per plant increased significantly with the increase of phosphorus levels up to $11.25 \mathrm{~kg}$ $\mathrm{ha}^{-1}$ and then decreased above this level. The highest number of pods per plant (57.67 plant $^{-1}$ ) was found in $\mathrm{P}_{5}$ treatment which was statistically superior to the rest of the treatments. The lowest number of pods per plant (30.67 plant $^{-1}$ ) was observed in the control plants. The results of the experiment were in accord with those of Ramasamy et al., (2000) where it was reported that P at $80 \mathrm{~kg}$ ha $^{-1}$ produced significantly higher number of pods per plant of soybean. Shivakumar and Sidramappa (2004) also found that the high- 
est number of pods per plant of soybean with $40 \mathrm{~kg} \mathrm{P} \mathrm{ha}{ }^{-1}$. Sharma and Namdeo (1999) observed that pods plant $^{-1}$ of soybean were greatest with $75 \mathrm{~kg} \mathrm{P}^{-1}$ and Rhizobium + FYM +PSB. Mohan and Rao (1997) also found that number of pods plant ${ }^{-1}$ of soybean increased with increasing $\mathrm{P}$ and Mo rates. treatments. The lowest number of seeds (1.82) pere pod was obtained by control plants. Sharma and Namdeo (1999) observed that seeds pod $^{-1}$ of soybean were greatest with $75 \mathrm{~kg} \mathrm{P} \mathrm{ha}{ }^{-1}$ and Rhizobium + FYM + PSB. Srivastava and Ahlawat (1995) also found that number of seeds/pod of pea increased

\section{Table III. Effect of phosphorus on yield and yield attributes of soybean}

\begin{tabular}{|c|c|c|c|c|c|}
\hline Treatment & $\begin{array}{l}\text { Number of } \\
\text { pods plant }^{-1}\end{array}$ & $\begin{array}{l}\text { Number of } \\
\text { seeds pod }^{-1}\end{array}$ & $\begin{array}{l}\text { Pod weight } \\
\text { plant }^{-1} \text { (g) }\end{array}$ & $\begin{array}{l}\text { Number of } \\
\text { seeds plant }{ }^{-1}\end{array}$ & $\begin{array}{l}\text { Seed weight } \\
\text { plant }^{-1}(\mathrm{~g})\end{array}$ \\
\hline $\mathrm{P}_{1}\left(0 \mathrm{~kg} \mathrm{ha}^{-1}\right)$ & $30.67 \mathrm{~d}$ & $1.82 \mathrm{~b}$ & $6.35 \mathrm{e}$ & $55.67 \mathrm{~d}$ & $4.06 \mathrm{~d}$ \\
\hline $\mathrm{P}_{2}\left(4.50 \mathrm{~kg} \mathrm{ha}^{-1}\right)$ & $33.33 \mathrm{~cd}$ & $1.83 \mathrm{~b}$ & 7.11de & $61.00 \mathrm{~cd}$ & $4.47 \mathrm{~cd}$ \\
\hline $\mathrm{P}_{3}\left(6.75 \mathrm{~kg} \mathrm{ha}^{-1}\right)$ & 38.67 c & $1.85 \mathrm{a}$ & $8.48 \mathrm{~cd}$ & $71.67 \mathrm{c}$ & $5.24 \mathrm{c}$ \\
\hline $\mathrm{P}_{4}\left(9.00 \mathrm{~kg} \mathrm{ha}^{-1}\right)$ & $50.33 \mathrm{~b}$ & $1.86 \mathrm{a}$ & $10.99 \mathrm{ab}$ & $93.67 \mathrm{~b}$ & $6.64 \mathrm{ab}$ \\
\hline $\mathrm{P}_{5}\left(11.25 \mathrm{~kg} \mathrm{ha}^{-1}\right)$ & 57.67 a & $1.87 \mathrm{a}$ & $12.56 \mathrm{a}$ & 107.67 a & $7.50 \mathrm{a}$ \\
\hline $\mathrm{P}_{6}\left(13.50 \mathrm{~kg} \mathrm{ha}^{-1}\right)$ & $47.33 \mathrm{~b}$ & $1.86 \mathrm{a}$ & $10.20 \mathrm{bc}$ & $88.00 \mathrm{~b}$ & $6.20 \mathrm{~b}$ \\
\hline LSD & 7.299 & 0.0178 & 1.725 & 13.14 & 0.966 \\
\hline CV (\%) & 9.54 & 2.01 & 10.44 & 9.28 & 9.55 \\
\hline
\end{tabular}

Means in a column followed by same letter (s) are not significantly different at 5\% level of DMRT

\section{Number of seeds per pod}

The effect of different levels of phosphorus with Bradyrhizobium inoculation on the number of seeds per pods of soybean was found significant (Table III). With the increase of phosphorus fertilizers levels increased the number of seeds per pod up to $11.25 \mathrm{~kg} \mathrm{P} \mathrm{ha}^{-1}$ and then declined. The highest number of seeds (1.87) per pod was found in $\mathrm{P}_{5}$ treatment which was $2.75 \%$ higher than that of control plants. $\mathrm{P}_{5}$ treatment was statistically similar to $\mathrm{P}_{6}, \mathrm{P}_{4}$ and $\mathrm{P}_{3}$ with increasing P rate. Sundara et. al. (2004) noticed that the application of $80 \mathrm{~kg} \mathrm{P}_{2} \mathrm{O}_{5} /$ ha resulted in the highest number of seeds per pod (5.74) of pea.

\section{Pod weight per plant}

With the variation of different phosphorus levels along with Bradyrhizobium inoculation, the pod weight of soybean varied significantly (Table III). It was found that the pod weight per plant increased significantly 
with the increase of phosphorus levels up to $\mathrm{P}_{5}$ treatment and declined in $\mathrm{P}_{6}$ treatment. The maximum pod weight (12.56 g) per plant was found in $\mathrm{P}_{5}$ treatment at $11.25 \mathrm{~kg} \mathrm{P}$ ha $^{-1}$ which was $97.80 \%$ higher than that of control treatment. The lowest pod weight (6.35 g) per plant was recorded in control plants. Shivakumar and Sidramappa (2004) in a similar experiment obtained the highest pods weight per plant of soybean with $40 \mathrm{~kg}$ P ha ${ }^{-1}$. Trivedi et. al. (1995) received increased pod yield of groundnut with $\mathrm{P}$ application at $22 \mathrm{~kg} / \mathrm{ha}+$ pressmud at 5.0 t/ha. El-Habbasha et. al. (2005) also noticed that increasing $\mathrm{P}$ levels increased weight of pods per plant of groundnut.
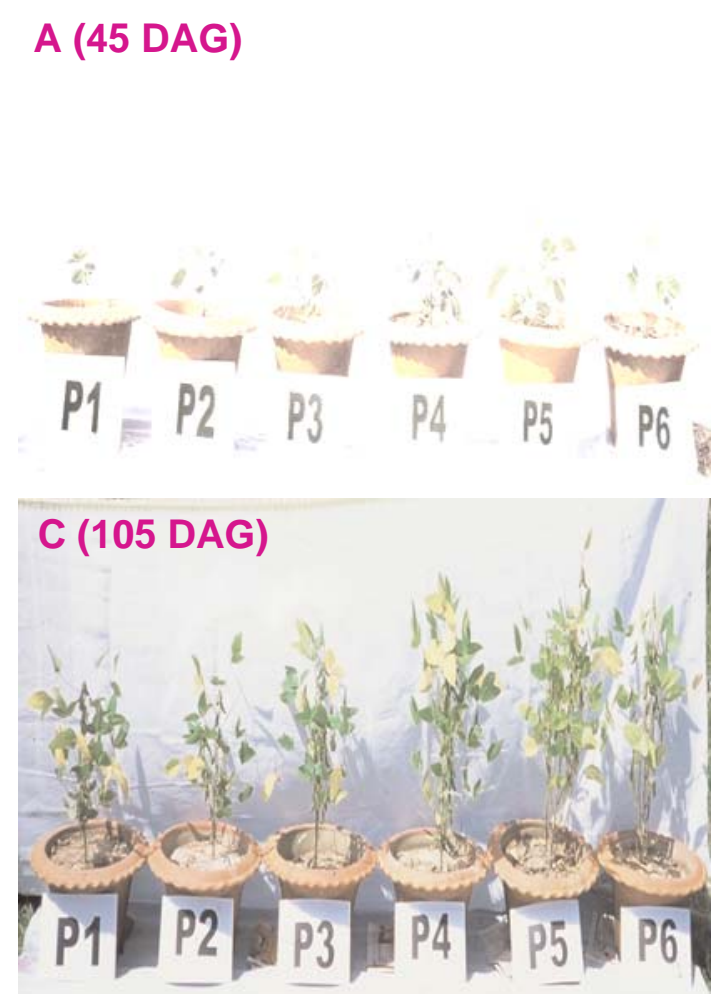

\section{Number of seeds per plant}

There was a significant effect of different levels of phosphorus with Bradyrhizobium inoculation on the number of seeds per plant of soybean (Table III). The number of seeds per plant was found to be increased gradually up to $11.25 \mathrm{~kg} \mathrm{P} \mathrm{ha}^{-1}$ of $\mathrm{P}_{5}$ treatment and then declined. Treatment $\mathrm{P}_{5}$ produced the maximum number of seeds (107.67) per plant which was statistically superior to the rest of the treatments. The lowest number of seeds (55.67) per plant was recorded by control plants. El-Habbasha et. al. (2005) noticed that increasing $\mathrm{P}$ levels increased
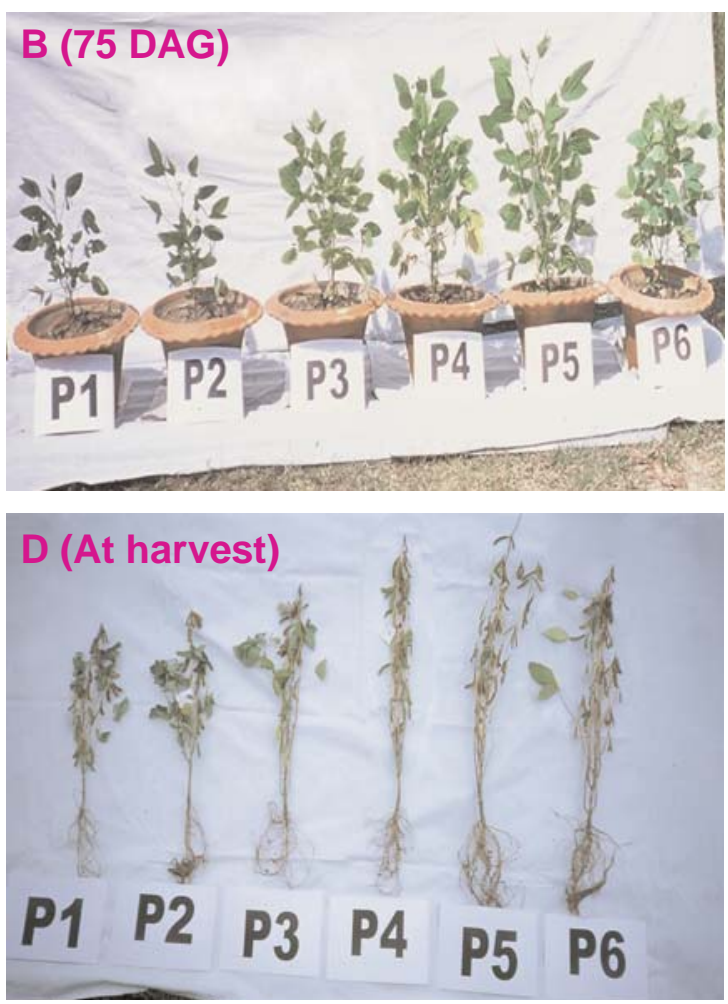

Fig. 1. (A-D) Comparison between control $\left(P_{1}\right)$ and different treatments phosphorus of at 45 (A), 75 (B), 105 (C) days after germination (DAG) and at harvest (D) 
number of seeds per plant of groundnut. Zafar et. al. (2003) also found that the application of $75 \mathrm{~kg} \mathrm{P}_{2} \mathrm{O}_{5} /$ ha gave the highest number of seeds per plant (1.89) of lentil.

\section{Seed weight of soybean}

The effect of different levels of phosphorus along with Bradyrhizobium inoculation on seed weight of soybean was found significant (Table III). The highest seed weight (7.50 g) was obtained by $\mathrm{P}_{5}$ treatment which was $84.73 \%$ higher than that of control plants. With the increase of phosphorus levels, increased the seed weight of soybean up to $11.25 \mathrm{~kg} \mathrm{P} \mathrm{ha}^{-1}$. The lowest seed weight (4.06 g) per plant was recorded by controlplants. Shivakumar and Sidramappa (2004) found that the highest grain yield of soybean obtained with $40 \mathrm{~kg} \mathrm{P} \mathrm{ha-1}$. Sharma and Namdeo (1999) also observed that seed yield of soybean were greatest with $75 \mathrm{~kg} \mathrm{P} \mathrm{ha}^{-1}$ and Rhizobium + FYM +PSB. Mohan and Rao (1997) found that seed yield of soybean increased with increasing $\mathrm{P}$ and Mo rates.

\section{Conclusion}

It may be concluded that phosphorus has positive effect on growth and yield of soybean. Application of phosphorus up to 11.25 $\mathrm{kg} \mathrm{ha}^{-1}$ (which was 25\% higher than BARC recommendation) gave the highest growth and yield of soybean as compared to other treatments including the control. So, application of P should be increased 25\% higher over BARC recommendation for better yield of soybean in Jahangirnagar University farm.

\section{References}

BARC. 1997. Fertilizer Recommendation Guide -1997. Farmgate, New Airport Road, Dhaka-1215.

El-Habbasha, S.F. Kandil, A.A. Abu Hagaza, N.S. El Haleem, A.K.A. Khalafallah M.A. Behairy ,T.G.( 2005) Effect of phosphorus levels and some bio-fertilizers on dry matter, yield and yield attributes of groundnut. Bulletin of Faculty of Agriculture, Cairo University. 56(2): 237-252.

Gates, C.T. (1975) Nodule and plant development in stylosanthes humilis symbiotic response to $\mathrm{P}$ and $\mathrm{S}$. Phosphorus in Agril: pp.53-65.

Gomez, A.K. Gomez, A.A. (1984) Statistical procedures for Agricultural Research. Second edition, John Wiley and Sons. New York. U.S.A.

Hoque, M.S. Ali, M. Mannan, M.A. (1980) Response of Bragg soybean to inoculation with different strains of Rhizobium japonicum. Thai. J. Agric. Sci. 13: 303-314.

Idri, M. Mahmood, T. Malik, K.A. (1989) Response of field grown chickpea to phosphorus fertilizer for yield and nitrogen fixation. Plant and Soil. 114(1): 135-138. 
Kaul, A.K. Das, M.L. (1986) Oilseeds in Bangladesh. Bangladesh Canada Agriculture Sector Team, Ministry of Agriculture, Govt. of the People's Republic of Bangladesh, Dhaka. p. 324.

Meshram, A.T. Jadhav, A.C. Konde, B.K. Wani, P.V. (2000) Effect of VAM fungi and Psources on nodulation, dry matter and yield of chickpea. Journal of Maharashtra Agricultural Universities. 25(1): 99-101.

Mohan, K.K. Rao, L.M. (1997) Effect of phosphorus and molybdenum on growth, nitrogen fixation and yield of soybean (Glycine max L.). Journal of Research ANGRAU. 25(4): 77-80.

Ramasamy, M. Srinivasan, K.Sankaran, N. (2000) Effect of 'P' mobilizers and different levels of phosphorus on growth and yield of Co.1 soybean. Madras Agricultural Journal. 87(10/12): 674-675.

Sharma, K.N. Namdeo, K.N. (1999) Effect of biofertilizers and phosphorus on growth and yield of soybean [(Glycine max (L.) Merrill)]. Crop Research Hisar. 17(2): 160-163.

Shivakumar, B.G Sidramappa, S.N. (2004) Influence of sources and levels of phosphorus with and without phosphorus solubilizing bacteria (PSB) seed treatment on growth and yield of soybean. Annals of Agricultural Research. 25(2): 333-334.
Singh, B.G. Rao, V.J.M. Suguna, C.A Rao, L.M. (1987) Varietal differences in growth and yield of mungbean (Vigna radiata) during summer and Kharif seasons. J. Plant physiol. 32: 207-214.

Singh, K.K. Srinivasarao, C. Masood Ali. (2005) Root growth, nodulation, grain yield, and phosphorus use efficiency of lentil as influenced by phosphorus, irrigation, and inoculation. Communications in Soil Science and Plant Analysis. 36(13/14): 1919-1929.

Singh, K.P. Ahuja, K.N.(1985) Dry matter production, oil content and nutrient uptake in groundnut as affected by fertilizers and plant density. Indian J. Agron. 30: 40-45.

Singh, R. Sharma, S.P. Bhatia, I.S. (1973) Effect of phosphate and molybdenum on the utilization uptake of nitrogen at flowering and maturity of soybean. J. Res. Punjab Agric. Univ. 9(4): 631-637.

Singh, V.K. Bajpai, R.P. (1990) Effect of phosphorus and potash on the growth and yield of rainfed soybean. Indian J. Agron. 35: 310-315.

Srivastava, T.K. Ahlawat, I.P.S. (1995) Response of pea (Pisum sativum) to phosphorus, molybdenum and biofertilizers. Indian Journal of Agronomy. 40(4): 630-635. 
Sundara, T.H. Vyakaranahal, B.S. Shekhargouda, M. Shashidhara, S.D. Hosamani, R.M. (2004) Influence of phosphorus and micronutrients on seed yield and quality of pea (Pisum sativum L.). Seed Research. 32(2): 214-216.

Trivedi, B.S. Bhatt, P.M. Patel, J.M. Gami, R.C. (1995) Increasing efficiency of fertilizer phosphorus through addition of organic amendments in groundnut. Journal of the Indian Society of Soil Science. 43(4): 627629.
Zafar, M. Maqsood, M. Anser, M.R. Zahid Ali. (2003) Growth and yield of lentil as affected by phosphorus. International Journal of Agriculture and Biology. 5(1): 98-100.

Received : March, 12, 2008;

Accepted : May, 04, 2008. 